\title{
UJI TOKSISITAS EKSTRAK Selaginella willdenowii TERHADAP KELANGSUNGAN HIDUP JUVENIL IKAN MAS (Cyprinus sp.)
}

\section{TOXICITY TEST OF Selaginella willdenowii EXTRACT ON SURVIVAL OF COMMON CARP JUVENILE (Cyprinus sp.)}

\author{
Akmalia Rahmani ${ }^{1}$, Endang L. Widiastuti ${ }^{1}$, M Kanedi $^{1}$, G. Nugroho Susanto ${ }^{1}$ \\ ${ }^{1}$ Jurusan Biologi FMIPA Universitas Lampung \\ E-mail:akmalia_rahmani@yahoo.com \\ Jurusan Biologi FMIPA Universitas Lampung \\ Jl. Soemantri Brojonegoro No.1, Bandar Lampung, Lampung, Indonesia, 35145
}

\begin{abstract}
Abstrak
Selaginella willdenowii merupakan jenis tumbuhan yang memiliki senyawa aktif biflavonoid hasil dari metabolit sekunder. Sifat toksik Biflavonoid diduga mampu menghambat pertumbuhan sel kanker. Jika asumsi ini benar, Selaginella dapat dikembangkan sebagai bahan baku obat tradisional. Penelitian ini bertujuan untuk mengetahui tingkat toksisitas ekstrak Selaginella willdenowii terhadap ikan mas juvenil. Ekstrak dibuat dari keseluruhan bagian Selaginella yang dimaserasi dengan menggunakan aquades, kemudian ekstrak dipanaskan di dalam oven sampai menjadi pasta. Pasta tersebut diencerkan menggunakan aquades hingga didapatkan ekstrak cair dengan konsentrasi yang berbeda yaitu $0 \%, 5 \%, 10 \%, 20 \%, 40 \%, 50 \%$. Masing-masing konsentrasi kemudian dituangkan pada media air ikan mas juvenil. Penelitian menggunakan rancangan acak lengkap (RAL) dengan 3 kali ulangan. Analisis data menggunakan ANOVA dengan a $5 \%$. Hasil penelitian menunjukkan bahwa ekstrak Selaginella willdenowii menggunakan aquades tidak cukup memberi efek racun yang dapat mempengaruhi hidup juvenile ikan mas karena nilai toksiknya tidak lebih besar dari $1000 \mu \mathrm{g} / \mathrm{ml}$ walaupun dapat meningkatkan nilai mortalitas ikan mas yang dapat terlihat pada konsentrasi $50 \%$ dan hal ini tidak menunjukkan adanya perbedaan yang nyata dengan konsentrasi yang lebih rendah.
\end{abstract}

Kata kunci :Selaginella willdenowii, Uji Toksisitas, Ikan Mas (Cyprinus sp.)

\begin{abstract}
Selaginella willdenowii is one of plants producing bioactive substance, biflavonoid as its secondary metabolites. Biflavonoid is toxic and assumed to inhibit the growth of cancer cells. This assumption leads to the use of selaginella as one of traditional medicines. This study was conducted to determine the toxicity level of Selaginella willdenowii extract on Cyprinus $\mathrm{sp}$ juvenile. Maceration by using aquadest was made for selaginella in order to get the extract and followed by dehydration using heating oven to get paste of the extract. The pasted extract then was used by diluting with aquadest and made in different concentration namely $0,5,10,20,40,50 \%$. Each concentration was applied to Cyprinus sp juveniles. Randomized design was applied to this study with 3 replications. ANOVA with a $5 \%$ significance was applied. The result indicated that the highest percentage mortality was showed by $50 \%$ extract concentration. However, based on the toxic value $<1000 \mu \mathrm{g} / \mathrm{ml}$, the $50 \%$ of Selaginella willdenowii did not show any toxicity on the Cyprinus sp. juvenile as well it did not significantly different compare to those lower concentrations.
\end{abstract}

Keyword: Selaginella willdenowii, Toxicity Test, Common Carp (Cyprinus sp.)

\section{PENDAHULUAN}

Selaginella willdenowii merupakan salah satu jenis tumbuhan paku yang banyak dijumpai di hutan sekunder. Di Indonesia dikenal berbagai jenis selaginella yaitu: Selaginella aristata, $S$. ciliaris, S. frondosa, S. intermedia, S. involvens, S. longiaristata, S. opaca, S. ornata, S. plana, S. remotifolia, S. repanda, S. rothertii, S. singalanensis, S. subalpina, S. willdenowii, S. zollingeriana, S. angustiramea,S. caudata,
S. velutina, S. cupressina, S. vonroemeri, dan S. ketra-ayam, S. mayeri dan Selaginella willdenowii banyak digunakan dalam penelitian karena banyak mengandungan zat-zat kimia yang bermanfaat sebagai bahan baku obat. Ekstrak Selaginella banyak mengandung biflavonoid, 4,7-di-O-metilamentoflavon, isokriptomerin, dan 7-O-metilrobusta-flavon yang secara signifikan sitotoksik terhadap berbagai sel kanker (Silva et al. 1995). Menurut Thomson 
(2007), kandungan kimia yang banyak terdapat pada Selaginella tersebut, dapat bermanfaat sebagai sebagai anti kanker. Selaginella juga memiliki manfaat sebagai bahan baku antioksidan (Chikmawati et al, 2009). Biflavonoid yang paling kuat dalam menghambat sel kanker adalah ginkgetin (Kim dkk., 2001). Untuk membuktikan bahwa Selaginella willdenowii ini memiliki sifat toksik seperti Selaginella yang lain, maka perlu dilakukan uji toksisitas.

Toksisitas Selaginella bisa diuji bertahap pada organisme hidup, salah satunya adalah ikan mas. Menurut Lilis (2006), Salah satu parameter pengujian bahan toksik terhadap hewan uji adalah $\mathrm{LD}_{50}$ atau $\mathrm{LC}_{50}$. Suatu tumbuhan dikatakan bersifat toksik bila konsentrasi yang digunakan menye-babkan kematian sebanyak $50 \%$ dari organisme uji.

\section{BAHAN dan METODE}

\section{Pembuatan Ekstrak Tanaman Selaginella}

Akar, batang, dan daun Selaginella dikeringkan di dalam oven dengan suhu $40-50{ }^{\circ} \mathrm{C}$ selama $5 \times 24$ jam sampai benar-benar kering. Selanjutnya, Selaginella yang telah kering dipotongpotong dan dihaluskan dengan blender kering. Selaginella yang telah halus direndam selama 24 jam kemudian disaring, langkah ini diulang sebanyak 3 kali sampai dihasilkan ekstrak. Ekstrak Selaginella kemudian digoyang dengan shaker selama 24 jam pada kecepatan rendah agar ekstrak homogen. Tahap terakhir, ekstrak Selaginella kemudian diuapkan di dalam oven dengan suhu $40-50^{\circ} \mathrm{C}$ hingga menjadi pasta dan siap digunakan sebagai larutan stok pada penelitian.

\section{Persiapan Wadah Hewan Uji}

Wadah yang digunakan sebanyak 18 buah toples dengan ukuran $2.500 \mathrm{ml}$ yang telah disterilkan dan diisi air sebanyak $1.000 \mathrm{ml}$.

\section{Perlakuan Ekstrak Selaginella Terhadap He- wan Uji}

Hewan uji yang digunakan dalam uji toksisitas adalah ikan mas dengan bobot $\pm 3 \mathrm{~g}$ per individu. Hewan uji dipelihara dalam 18 toples yang telah diisi air. Masing-masing toples berisi 3 ekor ikan mas dengan 3 pengulangan.

\section{Pengambilan Data}

Pengamatan dilakukan dengan menghitung jumlah ikan mas yang mati di setiap wadah pada 12 jam, 24 jam, 36 jam, 48 jam, 60 jam, 72 jam, 84 jam, dan 96 jam setelah perlakuan pada tiap konsentrasi.

\section{Parameter Penelitian}

Persentase Mortalitas Juvenil dihitung dengan rumus: (juvenil mati/ jumlah total juvenil) $x 100 \%$

Untuk mencari angka probit dibuat persamaan garis : $\mathbf{Y}=\mathbf{b X}+\mathbf{a}$

dimana $Y=\log$ konsentrasi

$\mathrm{X}=$ Angka probit

\section{Analisis Data}

Penelitian ini disusun dengan menggunakan rancangan acak lengkap (RAL) dengan 3 kali pengulangan. Dengan konsentrasi $0 \%, 5 \%$, $10 \%, 20 \%, 40 \%$, dan $50 \%$. LC 50 dicari dengan persamaan regresi linier yang merupakan hubungan antara konsentrasi dengan persentase kematian. Untuk mengetahui adanya perbedaan yang signifikan antar perlakuan, data dianalisis dengan menggunakan varian satu $\operatorname{arah}($ ANOVA) $(\alpha=0,05)$.

\section{HASIL dan PEMBAHASAN}

\section{A. Nilai Mortalitas Ikan Mas}

Tabel 1. Mortalitas juvenil ikan mas karena diberi ekstrak Selaginella wildenowii

\begin{tabular}{cc}
\hline Konsentrasi & Nilai Mortalitas (\%) \\
\hline $0 \%$ & 11,11 \\
$5 \%$ & 11,11 \\
$10 \%$ & 33,33 \\
$20 \%$ & 33,33 \\
$40 \%$ & 44,44 \\
$50 \%$ & 55,55 \\
\hline
\end{tabular}

Table 1. di atas menunjukkan peningkatan kematian pada setiap penambahan konsentrasinya, namun persentase mortalitasnya tidak menunjukkan perbedaan yang nyata pada setiap konsentrasi yaitu dapat dilihat pada konsentrasi $0 \%$ memiliki nilai mortalitas yang sama dengan $5 \%$. Hal ini diduga konsentrasi ekstrak aquades Selaginella $5 \%$ belum memiliki daya toksik jika dibandingkan dengan kontrol. Nilai toksik dari ekstrak aquades Selaginella mulai terlihat pada konsentrasi yang lebih tinggi yaitu pada konsentrasi $10 \%$ dan $20 \%$. Demikian juga pada penambahan konsentrasi selanjutnya yaitu $40 \%$ jumlah kematian juvenil ikan mas semakin meningkatkan yaitu sebesar $44,44 \%$, begitu juga dengan konsentrasi tertinggi $50 \%$ yang mengalami mortalitas yang paling tinggi diantara konsentrasi yang lain sebesar $55,55 \%$. Menurut Chikmawati (2009), S. willdenowii memiliki sifat 
toksik karena adanya kandungan saponin yang lebih tinggi daripada jenis Selaginella lainnya.

\section{B. Korelasi antara ekstrak Selaginella de- ngan nilai mortalitas ikan mas}

Hubungan rerata kematian juvenile ikan mas dengan besarnya konsentrasi ekstrak Selaginella yang diberikan dapat dilihat pada Gambar 1 berikut.

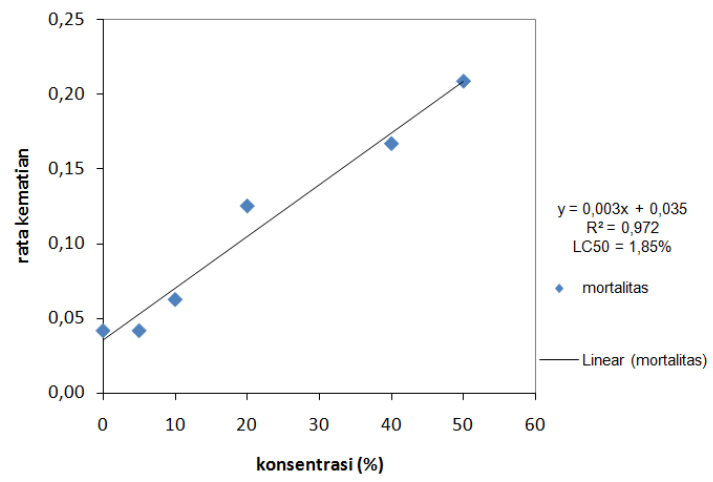

Gambar 1. Hubungan antara mortalitas ikan mas dengan peningkatan konsentrasi ekstrak Selaginella

Gambar 1 di atas menjelaskan tentang hubungan antara nilai rerata mortalitas juvenile ikan mas yang diberi ekstrak selaginella dengan tingkatan konsentrasi yang berbeda. Hal ini diduga karena ekstrak Selaginella yang mengandung biflavonoid dapat menimbulkan kematian ikan mas. Pada Gambar 1 di atas juga terlihat adanya korelasi antara rerata mortalitas dengan peningkatan konsentrasi ekstrak, dengan adanya nilai $R=0,972$ yang hampir mendekati 1. Angka tersebut menunjukkan bahwa hubungan antara penambahan konsentrasi ekstrak Selaginella sangat mempengaruhi kematian ikan mas. Nilai LC50 dihitung dengan memasukkan nilai 50 kedalam persamaan regresi $y=0,003(50)+0,035=18,5 \%$, dengan kata lain nilai $L_{50}$ sebesar 18.500 ppm. Hal ini menunjukkan bahwa nilai $\mathrm{LC}_{50}$ kurang toksik dalam mempengaruhi hidup juvenil ikan mas. Sedangkan pada pengamatan perjam dari 12 jam setelah perlakuan sampai 96 jam didapatkan hasil mortalitas yang berbeda-beda. Pada 12 jam setelah perlakuan dan 24 jam selanjutnya didapatkan angka probit sebesar $\mathrm{y}=0$, hal ini diduga karena ikan mas masih beradaptasi dengan perlakuan yang diberikan sehingga tidak terjadi mortalitas pada jam tersebut.

Sebagian ikan mas mengalami kematian yang tinggi pada jam ke-36 hampir untuk setiap konsentrasi yang diujikan. Gambar 2 menunjukkan bahwa pemberian ekstrak Selaginella yang berbeda pada ikan mas cukup mempe- ngaruhi kelangsungan hidup ikan. Hal ini dapat dilihat dengan nilai $R=0,693$. Pada 36 jam setelah perlakuan juga terlihat terjadi peningkatan persentase kematian pada setiap konsentrasi yang berbeda. Hal ini juga terlihat pada konsentrasi $50 \%$ yang mengalami peningkatan tertinggi sebesar $0,7 \%$ apabila dibandingkan dengan konsentrasi lainnya

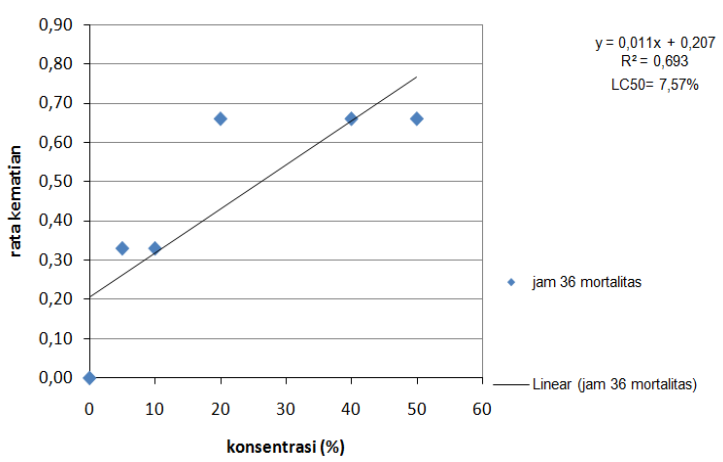

Gambar 2. Hubungan antara mortalitas ikan mas dengan peningkatan konsentrasi ekstrak Selaginella wildenowii setelah 36 jam.

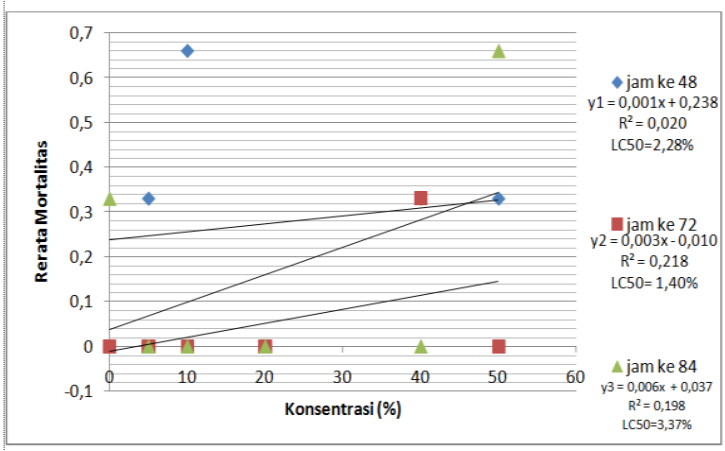

Gambar 3. Hubungan antara mortalitas ikan mas dengan peningkatan konsentrasi ekstrak Selaginella wildewii pada 48, 72, 84 jam

Dari ketiga waktu berbeda diatas (48 jam, 72 jam, dan 84 jam) hewan uji sama-sama mengalami peningkatan nilai kematian pada konsentrasi $40 \%$ dan pada konsentrasi $50 \%$ meskipun ada yang mengalami penurunan persentase kematian namun hubungan antara penambahan konsentrasi dengan rerata persentase kematian sangat kecil. Secar visual pada saat 48, 72, dan 84 jam setelah perlakuan dengan konsentrasi berbeda, ikan yang terkena racun atau zat toksik sudah mengalami gejala-gejala seperti gerakan hiperaktif, menggelepar, lumpuh dan kemudian mengalami kematian pada konsentrasi 40\%. Sudarmo (1992), mengatakan bahwa hewan uji yang terkontaminasi racun memperlihatkan gejala stress bila dibandingkan dengan kontrol, yaitu ditandai dengan menurunnya nafsu makan, gerakan kurang stabil, dan cenderung berada di dasar. 
Pada saat 60 jam setelah perlakuan selanjutnya mengalami penurunan nilai mortalitas dengan angka probit $y=0,000 x+0,057 \quad R=0$ yang menunjukkan bahwa penambahan konsentrasi ekstrak Selginella sudah tidak mempengaruhi kematian hewan uji dan pada 96 jam didapatkan angka probit sebesar $\mathrm{y}=0$, hal ini diduga karena ekstrak Selaginella sudah tidak memberi efek racun terhadap hewan uji terlalu banyak karena semua zat sudah mulai tercampur dengan media air dan hewan uji sudah mengalami kekebalan terhadap zat toksik itu sendiri. Sesuai dengan pendapat Effendie (1979) bahwa secara klinis hewan yang terkontaminasi racun memperlihatkan gejala stress bila dibandingkan dengan kontrol yang ditandai dengan menurunnya nafsu makan, gerakan kurang stabil, dan cenderung berada di dasar, hal ini dilakukan untuk memperkecil proses biokimia dalam tubuh yang teracuni, sehingga efek lethal yang terjadi lebih lambat.

Meyer et al., (1982) menyebutkan bahwa ekstrak tanaman dikatakan toksik jika memiliki $\mathrm{LC}_{50}$ $<1.000 \mu \mathrm{g} / \mathrm{ml}$. Pada penelitian ini digunakan 20 $\mathrm{g}$ pasta sebagai larutan stok, apabila $20 \mathrm{~g}$ tersebut dijadikan ppm maka besaran ekstrak pasta tanaman yang digunakan adalah 200.000 ppm $\left(20^{5} \mu \mathrm{g} / \mathrm{ml}\right)$, hal ini menunjukkan bahwa Selaginella willdenowii tidak cukup toksik untuk mempengaruhi kelangsungan hidup juvenile ikan mas walaupun pada data terjadi peningkatan mortalitas ikan mas pada setiap penambahan konsentrasi yang berbeda. Pada penelitian sebelumnya, tanaman Selaginella yang sering dikenal dengan sebutan ketra ayam memiliki kandungan biflavonoid yang lebih banyak dari Selaginella jenis lain berupa ginkgetin, isoginkgetin, amentoflavon, morelloflavon, robustaflavon, hinokiflavon, saponin, dan ochnaflavon. Senyawa-senyawa ini memiliki struktur dasar yang serupa yaitu 5,7,4'-trihidroksi flavonoid, tetapi berbeda pada sifat dan letak ikatan antar flavonoid. Adanya kandungan biflavonoid sebesar 2,46 ppm yang terdapat pada Selaginella jenis ini yang menyebabkan toksisitas ekstrak menjadi lebih tinggi dibandingkan Selaginella jenis lainnya (Rahman et al. 2007).

\section{SIMPULAN}

Dari hasil pengamatan dan pembahasan dapat ditarik kesimpulan sebagai berikut:

1. Ekstrak Selaginella willdenowii tidak cukup toksik terhadap ikan mas juvenil.

2. Pada konsentrasi $50 \%$ ekstrak aquades Selaginella willdenowii tidak mampu memberi efek racun terhadap ikan mas juvenil dan hal ini tidak menunjukkan adanya perbedaan yang nyata dengan konsentrasi yang lebih rendah.

\section{DAFTAR PUSTAKA}

Chikmawati, T., A. Wijayanto, dan Miftahudin. 2009. Potensi Selaginella Sebagai Antioksidan. Bogor: FMIPA IPB

Effendie, M. I. 1979. Metode Biologi Perikanan. Gramedia Pustaka Utama. Jakarta.

Erlan. 2005. Pengaruh berbagai media terhadap pertumbuhan bibit mahkota dewa (Phaleria macrocarpa (Scheff.) Boerl.) di polibag. J. Akta Agrosia 7(2):72-75.

Kim, J. and E.J. Park. 2002. Cytotoxic anticancer candidates from natural resources. Current Medicine in Chemical Anti-Cancer Agents 2: 485-537

Lilis Suhaerah. 2006. Zoologi Vertebrata. Ardesigen. Bandung.

Madhuri, G. and A.R. Reddy. 1999. Plant blotechnology of flavonolds. Plant Biotechnology 16 (3): 179-199.

Meyer, B.N et al. 1982. Brine Shrimp : A Convenient General Bioassay for Active Plant Constituent. Plant Res Medica 45 : 31-34.

Rahman, M. Riaz M. Desai U.R. 2007. Synthesis of biologically relevant biflavonoids. Reviev. Chemistri and Biodiversity 4: 2495-2527.

Setyawan, A.D. 2011. Natural products from Genus Selaginella (Selaginellaceae). Nusantara Bioscience 3: 44-58.

Silva G.l et al. 1995.Cytotoxic biflavonoids from Selaginella wildenowii .J Phyto 4: 129-134.

Thomson G.,E. 2007. The Health Benefit of Traditional Chinese Plant Medicine: Weighing the scientific evidence. Australia: RIRDC Pr.

Yamaguchi, L.F., D.G. Vassao, M.J. Kato, and P. Mascio. 2005. Biflavonoids from Brazilian pine Araucaria angustifoliaas potentials protective agents against DNA damage and lipoperoxidation. Phytochemistry. 66: 2238-2247. 